\title{
The Rise of Non Conventional Energy Prompted the Reunderstanding and Division of Oil and Gas Migration in the Petroleum Industry
}

\author{
Yicong Peng ${ }^{1, *}$, Jianjun Chen ${ }^{2}$ \\ ${ }^{1}$ College of Geosciences and Engineering North China University of Water Resources and Electric \\ Power, Zhengzhou 450046 China \\ ${ }^{2}$ School of Earth Sciences and Engineering XI'AN Shiyou University, Xi'an 710065 China \\ *Corresponding Author.
}

\begin{abstract}
In recent years, with the development of coal bed methane, especially large-scale success shale oil and gas exploitation, People will not only in sedimentary basin energy re classified as conventional energy and non conventional energy, And the non conventional energy referred to an important aspect and a situation of tripartite confrontation of the conventional energy sources, new energy, In this paper, in the identity of non conventional energy in the future as a kind of new energy type, Analysis is made on the global and China's major non conventional energy, resources potential, exploration and exploitation of species status, Foundation and face geological theories and engineering problems on, Emphasis on non conventional energy and conventional energy relationship, Both belong to the Petroleum industry. Is called the non conventional energy, is compared with the conventional energy. Because, whether conventional or non conventional sources of energy, Basically are generated and preserved in the sedimentary basin, or that there is a close relationship with sedimentary basin. Coal bed methane, shale gas, oil sands, oil shale, tight oil and gas, it is called the non conventional energy. Compared with the conventional energy sources -- coal, oil, and gas. Obviously, there are many similarities between them. That is, all belong to the fossil energy, To form (coal) containing oil and gas basin. The formation, not only distribution and evolution of the basin development, And form, and conventional energy accumulation are closely linked, not separate. It can be said that most of the non conventional energy product belongs to the oil and gas in different periods, the same kind of energy at different stages, Research thinks, migration to bridge non conventional energy and conventional energy sources of oil and gas, Unconventional oil and gas is the inheritance and development of conventional oil and gas, Unconventional oil and gas is the extension and expansion of conventional oil and gas denotation, connotation .
\end{abstract}

Keyword: Non-conventional energy, conventional energy, sedimentary basin, oil and gas migration, reunderst anding and division, inheritance and development, denotation and connotation, petroleum Industry

\section{Generation}

In recent years, the world energy structure has changed significantly along with commercial exploitation of unconventional energy, namely, excepting unconventional energy of coal, oil, gas, electricity (coal, water and electricity) and new energy of solar energy, wind energy, bio-oil, nuclear power, a kind of energy represented by coalbed methane, shale gas and other energy have appeared, such as : Dense oil and gas, shale oil and gas, coalbed methane, deep basin gas, oil shale, oil sands, tar, thickened oil and natural gas hydrate. They not only alleviate the current shortage of conventional energy (oil) and pollution (coal), but also are safer and more reliable, cost reduction are easy to win the time for promotion, especially the unconventional energy opens up new energy paths for human beings thanks to its high variety, vast resources and wide distribution[1].

Countries such as Australia, Canada and the United States have been in the forefront of unconventional energy in the world. Coal bed methane production of Australia has reached $62.5 \times 10^{8} \mathrm{~m}^{3}$ in 2011 ; Canada has reached $125 \times 10^{8} \mathrm{~m}^{3}$ in 2012, and the United States has reached $560 \times 10^{8} \mathrm{~m}^{3}$ as early as 2009 . Shale gas has rapid development, Production of shale gas in Australia has reached $215 \times 108 \mathrm{~m}^{3}$ in 2012; the United States has reached an incredible production of $2653 \times 10^{8} \mathrm{~m}^{3}$, and production of shale oil has reached $1.6 \times 10^{8} \mathrm{t}$, In 2018 , Shale gas production reached $6072 \times 10^{8} \mathrm{~m}^{3}$, accounting for $58 \%$ of the total natural gas production.of course, tight sandstone gas and other energy in the United

ISSN: 0010-8189

(C) CONVERTER 2020

www.converter-magazine.info 
States have achieved good effect. Especially the successful mining of shale gas in the United States has been dubbed "the shale gas revolution", which makes the United States the first largest country for producing natural gas in the world[2].

Although China's shale gas geological research and exploration and development is relatively late, But it's moving fast . Shale gas formation mechanism research started in 2005, 2008 shale gas drilling, Fuling and Changning shale gas fields have been discovered and built successively. By the end of 2020, China's shale gas production will exceed 200 million tons $\times 10^{8} \mathrm{~m}^{3}$, Proven shale gas reserves $1.8 \times 10^{12} \mathrm{~m}^{3}$, It has surpassed Canada and ranked second in the world. In order to ensure national energy security and promote regional economic and social development, It has made new contributions[3,4].

How couldn't we know or know enough of unconventional energy? Actually situation is really not so; if coal bed methane had long been recognized in the past, it could be more regarded as a kind of harmful gas; for safety of coal mining, it could be exhausted and released into the air. Tight sandstone oil and gas, oil shale and other energy have been paid no attention for its low original price and uneconomical mining. Shale oil and gas and natural gas hydrate should be really found and regarded as new energy; shale oil and gas used to be only for research (evaluate whether it has hydrocarbon generation ability and hydrocarbon-generating potential), not for exploitation; natural gas hydrate is really a kind of new energy, of course, it also cannot be completely out of the relationship of conventional oil and gas. Hence, the successful mining of unconventional energy is firstly influenced by shortage of conventional energy and increasingly high oil prices, at the same time, benefit from breakthrough of understanding on geological theory and technical innovation.

\section{Unconventional Energy and its Relationship with Conventional Energy}

\subsection{Unconventional energy and its resources}

Unconventional oil and gas resource is now unable to use conventional methods and technical means for economical exploration and development, including coal bed methane, tight oil and gas, shale oil and gas, oil shale, oil sands and natural gas hydrate, etc. Scale of global unconventional oil energy has reached $4495 \times 10^{8} \mathrm{t}$, among them, shale oil has reached $2770 \times 10^{8} \mathrm{t}$; heavy oil has reached $658 \times 10^{8} \mathrm{t}$, and unconventional oil energy and conventional oil energy are basically equivalent; Scale of global unconventional gas resource has reached $3922 \times 1012 \mathrm{~m} 3$, among them, shale gas has reached $456 \times 1012 \mathrm{~m} 3$; tight gas has reached $210 \times 1012 \mathrm{~m} 3$, and unconventional gas is 8.3 times of conventional gas resources. Unconventional oil and gas which are with huge potential resources gradually become a new field for exploitation and development, and bring to more and more attention for each country and oil companies[5-7].

With the innovation of theoretical technology, we break through threshold for conventional reservoir physical property and theory of oil detection from traditional entrapment. Along with deepening cognition on theory of oil and gas and exploration and development technology, global unconventional oil and gas exploration and development has made a series of major breakthroughs in recent years, and global unconventional oil and gas production is rapidly rising around the world, In 2008, which has more than $6000 \times 104$ t, compared with 2001, it nearly doubled; unconventional gas production has more than $5600 \times 10^{8} \mathrm{~m}^{3}$, and the proportion accounting for global oil and gas production were $2 \%$ and $18 \%$ respectively. In 2015, the annual production of unconventional oil in the world reached $3.7 \times 10^{8} \mathrm{t}, 9 \%$ of global oil production; Annual production of unconventional gas $9273 \times 10^{8} \mathrm{~m}^{3}, 37 \%$ of global gas production. In 2020, China's unconventional oil and gas production will exceed 100 billion cubic meters.

Unconventional oil and gas resources are more and more important in global energy structure, and are strategic areas of oil and gas exploration in the future.

For study of unconventional oil and gas geology, we can date back to 1930s. But for low grade of resources, poor reservoir, complex accumulation mechanism and difficult exploration and development, unconventional oil and gas resources has not been valued by exploration industry. Until the 1990s, Schmoker and Gautier and other person of USGS (1995) had put forward the concept of "continuous oil and gas reservoir", which referred to tight sandstone, coal bed, shale and other oil and gas resources with oil and gas basin which are aggregated distribution in ISSN: 0010-8189 
unconventional reservoir, with unclear boundary between reservoir and cap rock, lack of clear oil and gas hydrosphere. Based on the concept, USGS has made an evaluation of tight sandstone gas, shale gas, basin center, coal bed methane, shallow microbes and natural gas resources and other gas, and guided evaluation of unconventional oil and gas resource in the United States. B.E.Law and other person (2002) have put forward concept of unconventional oil and gas system, and thought that it has nothing to do with structural trap, and has not been basically affected by gravity differentiation, and regionally has large-scale general regions containing oil and gas, and briefly introduces coal bed methane, deep basin gas, natural gas hydrate and other several kind of unconventional gas resources, and emphasizes technical difficulties and economic viability[8-10].

\subsection{Unconventional energy is with conventional energy in the sedimentary basin}

Unconventional energy has been called, which is relative to conventional energy, they are of intimate connection. Both conventional energy and unconventional energy are basically generated and hosted in sedimentary basin, or have inseparable relations with sedimentary basin. They are basically organic origin (besides mantle source gas, volcanic gas) and have occurred in sedimentary basin, that is to say, without sedimentary basin, there is no conventional and unconventional oil and gas.

Sedimentary basin is an area which sediment has larger accumulation rate in a certain geological period, and the deposit thickness is much larger than surrounding areas. Due to geotectonic location and geographic location of sedimentary basin are different, the size, style and age of sedimentary basins, type and distribution of sediment are different, and change according to geological period. Each basin not only has large differences, but also has its own characteristics, especially in aspects of formation energy, some of which can be formed, others cannot; for those which can be formed, some types of energy resources are single, some of which are diversity, some of which are enrichment, some of which are poor.

According to the view of conventional oil and gas formation and accumulation, definition and evaluation of petroleum-bearing basins in the past are that, petroleum-bearing basins are sedimentary basin which can find commercial oil and gas reservoir. Petroleum-bearing basins are firstly and foremost sedimentary basins. If we count according to 517 sedimentary basins, of which commercial oil and gas fields of different size have been found in 212 basins, and petroleum-bearing basins account for about $41 \%$. A petroleum-bearing basin must be of source bed, reservoir stratum, cap rock and overlying strata and other 4 petroleum geological factors and entrapment formation, hydrocarbon generation, migration and accumulation and other 4 petroleum geological processes[11].

In recent years, mining of bed methane achieved success in North America, especially in the United States. Especially shale gas has achieves major breakthrough, and has been dunned "the shale gas revolution", which will promote unconventional energy to a never reached height. Due to different methods of gathering and storage and different level of exploration, coal, oil and gas which are enrichment and easy to exploration are known as conventional energy; those are not quite gathering and difficult to exploration are known as unconventional energy, including coal bed methane, shale oil and gas, natural gas hydrate, oil shale, oil sand, asphalt, tight sandstone oil and gas, deep basin gas and so on, in addition to coal, oil, gas, which is theoretic foundation for sedimentary basins to form multiple energy.

2.3 Bituminous coal materials and source oil materials form two series of conventional and unconventional energy respectively

It can be divided into two types according to difference of hydrocarbon generation parent material: series formed by bituminous coal materials, such as coal, coal gas, coal bed methane, oil shale and so on; series formed by source oil materials, such as shale oil and gas, conventional oil and gas, thickened oil, oil sand, asphalt and so on.

Some basins contain nothing (hereinafter referred to as coal, oil, gas), which are just sedimentary basins; come basins contains coal, oil and gas, and this kind of basins should be subdivided into several types. In eastern region of China, sedimentary basins mostly are single Paleozoic, Mesozoic or Cenozoic basins, which causes separation of coal-bearing basins and oil-bearing basins; coal-bearing basins only contain coal, and oil-bearing basins only contain

ISSN: 0010-8189

(C) CONVERTER 2020

www.converter-magazine.info 
oil. This is not only related to organic matter type, but also to type, size, formation period of basins, type of sedimentary facies, structure development and late reconstruction and save. Coal-bearing basins form coal, oil shale, coal bed methane and a part of conventional coal bed gas reservoir[12].

Oil-bearing basins can be divided into shale oil and gas, tight sandstone oil and gas, conventional oil and gas and heavy oil, asphalt, oil sand formed by running to ground along fault or destroy of later reformation of native oil reservoir (light component escaping, oxidation, hydrolysis and biological damage, etc.) according to distance and migration of hydrocarbon source rocks.

And sedimentary basins in Midwest mostly are compound Paleozoic, Mesozoic and Cenozoic basins, so coal-bearing basins and oil-bearing basins are continuous superposition. Erdos Basin, Junggar Basin, Sichuan Basin, Tuha Basin are double source rock, namely coal petrography and kerogen, which can develop their own separate series. Such as: series of coal, coal bed methane, oil shale, coal gas, deep basin gas, flammable ice, oil sands, asphalt and source-mixing gas formed by tight gas, conventional gas, deep basin gas and flammable ice together.

Whether alone or composite series, oil and gas migration will happen along with corresponding changes of physical, chemical, biological conditions (temperature, pressure, catalyst, stress), namely progress of thermal evolution; oil and gas migration is going to happen, and as for its extent, which is related to space-time allocation, migration motivation, channels, etc. in addition to type of basin, sedimentation, structure and organic matter, abundance and thermal evolution.

\section{Bridge of Unconventional Energy and Conventional Energy is the Migration of Oil and Gas}

Coal bed methane, shale gas, oil sand, oil shale, tight oil and gas and other energy, which are called as unconventional energy, are related to conventional energy - coal, oil, gas. Obviously, they have many common characters, namely, they belong to fossil energy, which are formed in oil-bearing (gas-bearing) basins. The generation and distribution of unconventional energy are not only related to development and evolution of basin, but also closely related to formation and gathering of conventional energy. Most unconventional energy belongs to the same kind of oil and gas energy in different period and different stage. Compared with conventional energy, advantages of unconventional energy are more types, wide distribution, large resources, but the disadvantages is also very obvious, that is, low abundance, poor physical property and high cost.

We have a consensus that conventional oil and gas is to form oil and gas, and must go through operational maintenance of source reservoir cover and other several elements. Place of oil and gas generation (dark mudstone and shale) and place of oil and gas reservoir are not the same (sandstone, carbonate), which has experienced the primary, secondary migration. And unconventional oil and gas have various names, which has no uniform standards, and all types of oil and gas excepting conventional oil and gas are called unconventional oil and gas for the time being. In fact, it also has a bigger difference, for example, deep basin gas, tight sandstone oil and gas and oil sands have experienced primary, secondary migration, and six key elements in formation of oil and gas. Will it be attributed to conventional or unconventional energy? The question will be answered more scientific after people have a deeper understanding of oil and gas[13-15].

However, in any case, it is very necessary to re-classify and define the migration of oil and gas along with the increasingly rise of unconventional oil and gas.

Moreover, the rising of coal bed gas and shale gas has overturned the geological theory of conventional oil and gas. That is because the previous studies of conventional oil and gas mainly focus on the basic conditions, such as generation, migration and aggregation of oil and gas as well as their time and space combination. Especially for the source rock, the basic method is only research without exploration and exploitation. But nowadays the exploration and development of coal bed gas and shale gas are inside the scope of previous source rock; it has raised a new question for us, which is that any migration and aggregation of oil and gas exist inside source rock, and the answer is obvious.

ISSN: 0010-8189

(C) CONVERTER 2020

www.converter-magazine.info 
And along with the development of unconventional energy, especially the successful exploitation of shale oil and gas (certainly, including coal bed gas), people have a new understanding for the concept of petroliferous basin, which is that the most important one is hydrocarbon source rock. Thus, it can be seen that the so-called unconventional energy may not have the above-mentioned elements, such as generation, reservoir, cover, circle, transportation, protection and so on. Therefore, a new definition can be decided that the forming of conventional oil and gas in such a basin only with hydrocarbon-generating condition is hardly to say, because there are other conditions and space-time collocation to be considered, but the forming of unconventional oil and gas is definite.

A basin will either form energy or not form. If it is, there must be unconventional energy or conventional energy possibly. The main conditions which determine their formation and distribution are the completeness of basin, adequacy of hydrocarbon-generation, universality of deposition and tectonic diversity, and oil-gas migration will combine these energy sources.

In fact, unconventional energy and conventional energy are closely linked and cannot be separated from the aspect of cause of formation and source, formation condition and regularities of distribution. The migration energy during early phase (previous primary migration) is shale oil and gas mainly; the second migration energy is tight sandstone oil and gas (including coal bed gas) at initial stage, conventional oil and gas (including coal bed gas) at medium stage (second migration), and thickened oil, oil sand and asphalt at late stage (third migration)[16].

\subsection{Oil-gas migration was only divided into primary migration and second migration in the past}

Both petroleum and natural gas are fluid mineral products, and their biggest feature is the migration nature. The oil-gas migration mainly belongs to the fluid activities with hydrocarbonaceous generated inside the basin, whose space-time range is from underground hydrocarbon source rock to the earth surface.

The past situation is based on the cognition and exploration of $\mathrm{c}$, which mainly focuses on the existence of hydrocarbon source rock in a basin as well as its quantity and quality with only assessment and no exploitation. This is because conventional oil and gas are such a kind of energy which exists in the reservoir stratum and carries out oil and gas exploration and exploitation after through aggregation. Thus, the oil-gas migration can be divided into primary and second migration. The primary migration refers to the migration of oil and gas in hydrocarbon source stratum and the migration towards reservoir stratum or carry stratum. While the second migration refers to all migration of oil and gas after they enter reservoir stratum or carry stratum. It involves migration of oil and gas inside reservoir stratum or carry stratum, migration along the passageway of fault, fracture and plane of unconformity, as well as re-migration of aggregated oil and gas caused by the change of surrounding geological conditions[17].

\subsection{Unconventional oil and gas are the inheritance and development of conventional oil and gas}

Conventional oil and gas: six factors-generation, reservoir, cover, circle, transportation, protection as well as adjustment and damage. It is not wrong to only or mainly care about oil and gas reservoir - conventional oil and gas (formed in one process and after adjustment), because it is quite normal with the limitation of conditions of theoretical method and techniques at that time.

It has been mentioned above that unconventional oil and gas involve coal bed gas, shale oil and gas, tight sandstone oil and gas, deep basin gas, natural gas hydrate, oil sand, oil shale, heavy oil, asphalt, etc. Especially, unconventional oil and gas are very popular nowadays, which greatly expanded the exploration and exploitation field of fossil energy, and even changed the basin which considered having no value of exploration in the past to be the one with exploration value. However, it cannot be a reason to exclude and ignore the unconventional oil and gas. Why is it called unconventional oil and gas? That is because the name is relative to conventional oil and gas. The correct understanding attitude is the inheritance and development of conventional oil and gas but not an opposition[18].

ISSN: 0010-8189

(C) CONVERTER 2020 


\subsection{Unconventional oil and gas are the extension of conventional oil and gas}

If the conventional oil and gas are placed on the highlighted and turning position, which should be this in fact, then those in front of them are tight sandstone oil and gas, deep basin gas, natural gas hydrate; those far more in front of them are shale oil and gas and coal bed gas; those behind them are oil sand, asphalt, heavy oil, dry gas and oil shale damaged by oil deposit (or deepened evolved products).

Oil and gas substance has not changed; the change only happened on the space-time relationship, and from the aspect of time, it starts earlier and ends later; from the aspect of space, the range is wider both longitudinally and breadthwise.

3.4 Associated and separate role of oil-gas migration in unconventional and conventional oil and gas

According to the theory of conventional oil and gas, including Tissot's oil generation theory, oil-gas migration is divided into primary and second migration, which is familiar to everyone, and I will say nothing more.

Here, the migration inside the hydrocarbon source rock (or hydrocarbon source rock stratum) is called: previous primary migration, and coalbed gas, shale gas and shale oil are formed at this stage; the migration out of hydrocarbon source rock is called later primary migration or previous second migration, and tight oil, tight gas, deep basin gas and natural gas hydrate are formed at this stage; the migration damaged by oil deposit is called later second migration, and oil sand, thickened oil, asphalt and oil shale are formed at this stage.

\subsection{Big system concept and division}

Everyone is familiar with the petroleum system when talking about conventional oil and gas. Conventional and unconventional oil and gas are defined as a system here as I said before, and it can be called as an energy system when using oil-gas migration to combine them. Obviously, the range of energy system is bigger than petroleum system. And in this system, oil and gas cannot be divided in accordance with generation, reservoir, cover, circle, transportation, protection, but in accordance with shale gas and oil, tight gas and oil, conventional oil and gas, oil sand and asphalt.

\subsection{Enhancing of hydrocarbon generation quantity position}

According to the division of oil and gas primary and second migration and idea of seeking for conventional oil and gas, only an assessment will be carried out with no exploration and exploitation for hydrocarbon source rock. The research shall only focus on whether it is hydrocarbon source rock or not as well as its quantity and quality, and the rock is commonly known as dark-colored mud rock. The quantity refers to the number of stratum, thickness and range of dark-colored mud rock, shale and marlstone, whiles the quality refers to abundance, type, percent conversion and thermal evolution degree of organic matters.

Through the above studies, we can calculate the hydrocarbon-generation amount, hydrocarbon-emission amount, aggregation amount and dissipation amount. The exploration and exploitation of conventional oil and gas are mainly based on the aggregation amount. And along with the rise of unconventional oil and gas, the hydrocarbon-generation amount, hydrocarbon-emission amount and dissipation amount have been increased to an significant height; especially for exploration and exploitation of shale oil and gas, the hydrocarbon-generation amount, hydrocarbon-emission amount and dissipation amount have been increased to an unprecedented height, which attracts the attention of petroleum geology experts and oil-gas businessmen in various countries[19].

\section{The Following Conditions need to be Met When Numerous Types of Conventional and Unconventional Energy and Abundant Resources are Formed in a Basin}


Whether conventional resource or unconventional resource, not only they both belong to fossil energy, but also there is a close genetic relation between their formation and distribution; in addition, they both occur in sedimentary basin. Thus, whether energy can be formed, what kind of energies can be formed and whether types of energies are complete in a specific basin depend on type, property, size, depth of burial, depositional environment, late preservation and other conditions of a basin.

The crust in Xinjiang has gone through a long and tortuous development process, which provides adequate material source and space of minerals transfer and collection for mineralization, then forms rich mineral resources and provides broad development prospect for Xinjiang. Three large basins, namely Tarim Basin, Junggar Basin and Turpan-Hami Basin and small and middle-sized basins such as Yanqi Basin, Santanghu Basin and Ili Basin not only abound in abundant oil and gas, coal and other conventional energy with 1.6 trillion tons of coal and 20 to 40 billion tons of petroleum (including natural gas), but also contain shale gas of huge potential (26 trillion cubic meters), coal bed methane ( 9.5 trillion cubic meters), oil shale (120 billion tons) and other unconventional energies[20].

\subsection{Junggar Basin is large and typical with intergrowth of oil, gas, coal and unconventional energies}

Especially Junggar Basin is large and typical with intergrowth of oil, gas, coal and unconventional energies. Conventional energies: amount of coal resources exceeds 1 trillion tons and total amount of oil resources is 10.69 billion tons with 8.59 billion tons of petroleum and 2.1 trillion cubic meters of natural gas. Unconventional energies: amount of coalbed methane is 3.9150 cubic meters; shale gas is $38000 \times 108$ with 94.8 billion tons of oil shale resources and 131 million tons of oil sand reserves.

It is rare to see a basin like Junggar Basin with complete types of resources, rich amount of resources (reserves), wide distribution scope, numerous levels of geological age and high abundance among domestic and overseas basin containing coal, oil and gas. It is currently analyzed by taking Junggar Basin as example:

\subsubsection{Basin structure-sedimentary evolution}

Junggar Basin lies in the north of Xinjiang and is surrounded with fold mountain systems. The area of the basin is 134 thousand $\mathrm{km} 2$ with $14000 \mathrm{~m}$ of maximum thickness of sedimentary rock; the basin is a large unconventional energies yoked basin in northwest region, including oil, gas and coal.

Regional tectonic evolution went through Permian chasmic stage, depression stage from Triassic to late Oligocene and the shrinkage from Miocene epoch to now-entire stage of upgrade. Correspondingly, the sedimentary evolution underwent early Permian foreland marine face to residual marine basin, mid-late Permian foreland continental basin, Triassic-Paleogene oscillation continental basin, Neogene period to Quaternary period foreland continental basin, four stages in total. Polycycle activities of orogenic belts at the basin's verge had different effects on the basin evolution and the current structural framework is the result of motion-superposition[21].

\subsubsection{Conditions of conventional energies}

4.1.2.1 Petroleum formation

Junggar Basin develops carboniferous system, Permain, Triassic system, Jurassic system, cretaceous system and pelaeogene from bottom to top. Permain is the most import hydrocarbon source bed and mainly distributes in the central depression; Jurassic system is the second hydrocarbon source bed which is only less than Permain and expulses hydrocarbon at the thrust belt hidden deep places of front of North Tianshan; Cretaceous system and Paleogene hydrocarbon source bed are only distributed at the thrust belt of front of North Tianshan and the maturity is generally low.

\subsubsection{Natural gas formation}

Junggar Basin has favorable conditions for natural gas accumulation. The basin develops 5 sets of regional cover coats and multi-set regional belt-type cover coats.

ISSN: 0010-8189

(C) CONVERTER 2020 
Natural gas is abundant and the exploration potential is great, especially in Permain system and Jurassic system. Differences of natural gas in different belts and systems are great.

There are four important exploration fields of natural gas in the basin: Ludong- Wucaiwan region (mainly are Carboniferous, Jurassic and Cretaceous), Zhongguai- Wuba region (mainly Permain system), south edge thrust belt (mainly are Palaeogene and Neocene), deep and huge structure (mainly are Carboniferous system and Permain system).

\subsubsection{Coal formation}

The development process of Junggar Basin can be divided into four stages.

Stage I: filling and leveling up stage before coal accumulating (from late carboniferous to Triassic system)

Stage II: coal accumulating stage for the basin (early and middle Jurassic)

Stage III: cover coat formation stage in late coal accumulating (late Jurassic to the Tertiary period)

Stage IV: basin reconstructing stage (Quaternary period)

\subsubsection{Resource forecast of unconditional energies}

\subsubsection{Coal bed methane}

The coal bed methane in Junggar Basin is 3915 billion m3, which is mainly distributed in the south edge of the basin, especially in southeast edge. The main part is low rank coal with medium gas content and high permeability, which can achieve higher production.

\subsubsection{Shale gas}

According to the research, Junggar Basin develops lower Carboniferous series, upper Permian series, middle-lower Jurassic, palaeogene and many other sets of effective hydrocarbon source rocks. Of which Permain system is the most important hydrocarbon source rock series in the basin and it is the main series of strata to form shale gas and it mainly develops at the front of Bogeda mountain at the east of southern margin and the front of Carat Beautiful mountains at the northeastern margin[22].

\subsubsection{Oil shale}

The west of oil shale ore belt of Junggar Basin in Xinjiang is from Urumqi Yaome mountain to the east of Qitai baiyanggou with $281 \mathrm{~m}$ of thickness. The highest oil ratio is $28 \%$ and the average oil ratio is $8 \%$. Medial oil ratio of oil shale accounts for half and low oil ratio and high oil ration account for much proportion, about $1 / 4$ respectively, higher than the overall level of oil shale in our country.

\subsubsection{Oil sand}

Distribution of Karamay-Urho ground oil sand at the northwest margin of Junggar Basin is very wide, mainly concentrated on Hongshanliang ditch, Huashi ditch, Quanshui ditch in Hongshanzui area and Tuziakennei ditch, Heiyou hill, small oil groove in Karamay region and White ditch, Small Jurassic ditch in Baijiantan region and Youlishan and Bituminous Dike in Urho area. Oil sand is also distributed at Shaqiu River of eastern Junggar and the southern margin.

4.2 Seeing from Junggar Basin, a basin shall have the following conditions to be a basin with complete energy types and abundant resources

\subsubsection{Sequence integrity of basin succession and evolution is the premise}

Basin location, nature, type, size, age and preserve decides whether the basin has oil gas and conventional oil gas or not, especially, whether there is an integrated sequence of conventional and unconventional oil gas is the premise.

ISSN: 0010-8189

(C) CONVERTER 2020 
Junggar Basin was between the ancient Siberia Plate and Tarim Plate in Paleozoic and previous period, belonging to part of Junggar microplate of the eastern extension part of Kazakstan Plate, now to the constituent part of Eurasian plate. Kazakstan Plate is made of several microplates and the marginal active belts. The north is the Siberian ancient plate, which is connected with Qiaoxianlaha suture line; the south is Tarim paleo-plate, which is connected with the suture line of Han tender-Kanggultage. Thus it can be seen that Junggar Basin lies in the core stable region of Junggar plate and is a continental intraplate basin which is surrounded by three sides of Paleozoic suture lines developed from late Carboniferous epoch to Quatermary period[23].

\subsubsection{Types of source rocks and the sufficient amount are the keys}

The quality and amount of hydrocarbon generation shall be judged by the quality and amount of source rocks. The amount includes scope and thickness, the quality includes abundance, type, conversion and evolution. If the hydrocarbon generation capacity is too small to reach the basic hydrocarbon concentration requirement of primary migration, it may not form conventional petroleum. If the hydrocarbon generation capacity is large, with adjustment and destruction, it may form shale oil and gas, tight oil and gas, conventional petroleum, oil sand and bitumen and an integrated conventional and unconventional energy sequence.

Junggar Basin develops carboniferous system, Permain, Triassic system, Jurassic system, cretaceous system and pelaeogene from bottom to top. Permain is the most import hydrocarbon source bed and mainly distributes in the central depression; Jurassic system is the second hydrocarbon source bed which is only less than Permain and expulses hydrocarbon at the thrust belt hidden deep places of front of North Tianshan; Cretaceous system and Paleogene hydrocarbon source bed are only distributed at the thrust belt of front of North Tianshan and the maturity is generally low.

\subsubsection{The condition is the universality of sedimentary and structure}

Terrestrial lacustrine basin is an example. If a huge basin is in a long-term process of continuous sinking and accepting sediment and the sediment fits for the sedimentation rate and center, namely all kinds of sedimentary facies are complete, such as deep lacustrine face, semi-deep lacustrine face, shallow lacustrine face, shore lake face, swamp face, delta face, fluvial face (including upstream, midstream and downstream), conventional and unconventional oil and gas can be formed, including integrated energy sequence such as coal and coalbed methane.

Junggar Basin is a good example. Regional tectonic evolution went through Permian chasmic stage, depression stage from Triassic to late Oligocene and the shrinkage from Miocene epoch to now-entire stage of upgrade. Correspondingly, the sedimentary evolution underwent early Permian foreland marine face to residual marine basin, mid-late Permian foreland continental basin, Triassic-Paleogene oscillation continental basin, Neogene period to Quaternary period foreland continental basin, four stages in total. Polycycle activities of orogenic belts at the basin's verge had different effects on the basin evolution and the current structural framework is the result of motion-superposition.

Shale oil and gas is in the basin center, then outward is tight sandstone oil and gas; outer are conventional oil and gas, thickened oil, oil sand, asphalt, oil shale, coal, coalbed methane, etc.

4.2.4 Accumulation mechanism and abundance regularity of multi-energy resources coexistence in the basin Multi-energy resources basin has the characteristics of stages and trips in the distribution of earth crust. In the process of geological history, the evolution from the ancient plate to modern plate not only causes the differences of conventional energies and unconditional energies, structurally stable regions and unstable regions, but also causes the accumulation mechanism and abundance regularity of multi-energy resources coexistence.

Petroleum, natural gas, coal and coalbed methane, shale gas, oil shale, oil sand and asphalt are all the products of basin and there will be no such sedimentary mineral deposits without the sedimentary basin. Formation, transfer, accumulation, destruction of coalbed methane, shale gas and oil and gas are controlled by the formation and evolution of the basin which contains coal, coalbed methane, oil and gas. Paleoclimate, paleogeography,

ISSN: 0010-8189

(C) CONVERTER 2020 
paleontology, paleostructure and other factors decide the formation, evolution and distribution of basins; paleogeotemperature, paleopressure, paleostress and paleo-chemical field decide the formation, accumulation and distribution of energies, which decides the formation and preserve of conventional energies and unconventional energies. Coal bed methane, shale gas, oil shale, oil sand and asphalt are coexisting with oil and gas and coal. Their genetic mechanisms are similar but the deposited states are different. Formation conditions for (Junggar) basin include complete sedimentary facies types, deep lake, semi-deep lake, shallow lake, swamp, delta, fluvial face, proluvial and side rock face, unicellular lower eukaryote, plankton, fungus, alga, terrestrial higher plant environment, suitable temperature, structural environment, moderate buried depth and deposit, providing good time and space configuration for formation, coexistence and accumulation of multi-energy resources horizontally and vertically[24]. Conventional energies and unconventional energies are all organic mineral resources and coexist in sedimentary basins. Coal bed methane, coal, shale oil and gas and conventional oil and gas are syngenetic, coexisting mineral resources. Not only are the accumulation mechanisms similar, but also the occurrence of these resources is interlinked.

Take coal bed methane for example, the solid converted by organic materials of formed coal is coal petrography and the gas state is coal bed methane, coal reserves can still deposit coal upon diagenesis or structural damage, but they may not be coal gas reservoirs, thus it can be seen that the condition for coalbed methane reservoir forming is higher than the one of coal reserves. As fluid mine-there are more similarities between coal gas reservoir and conventional oil and gas reservoir. Conventional oil and gas reservoir (including coal gas) needs sufficient oil (gas) sources and petroliferous basins shall have good oil (gas) source beds; there shall have much reservoir space for dispersing hydrocarbon migration and accumulation and petroliferous basins shall have good reservoir stratums; there shall have preservation conditions for not being dispersed in the process of hydrocarbon migration and accumulation and petroliferous basins must have good sealing layers. Only these conditions can have oil and gas accumulated in the good trap. Although the gas source rock bed of coal bed methane is coal petrography, it must conform to the regularity of forming reservoir when free hydrocarbon gas is migrated and accumulated again, therefore coal bed methane shall be classified into conventional natural gas. Coal bed methane also requires the basins to have good hydrocarbon source rocks, namely gas yielding stratums and needs reservoir rocks which reserve gaseous hydrocarbon in form of adsorption state and also has good sealing layers and sealed hydrodynamic conditions[25].

\section{Conclusions and Suggestions}

No matter in time or in space, the rise of unconditional energies opens the field of looking for fossil energies in sedimentary basins and China can mine 60 years of coal bed methane and 200 years of shale gas, which firms the function of fossil energies being important roles of energies continuously.

The rise of shale oil and gas makes it necessary for us to newly estimate the basins that used to think that there was no hope. In the past, evaluating a basin whether it contains oil and gas, not only hydrocarbon source rocks shall be checked, but also whether there is reservoir stratum, cover coat and time and space configuration for oil and gas formation, transfer, accumulation and reserve, in such a way, basins which only have oil source beds are excluded naturally. With commercial-scale operation of unconventional oil and gas nowadays, especially shale oil and gas, it is very necessary to newly recognize and evaluate basins which only have source beds.

In terms of shale oil and gas development nowadays, the statement of shale thickness up to $30 \mathrm{~m}$ is debatable. Because Tissot ever said the effective thickness of primary hydrocarbon expulsion is $14 \mathrm{~m}$ up and down respectively, this is why some researchers determined it to be $30 \mathrm{~m}$. Specific problems shall be analyzed according to specific conditions, the thickness is related to type of organic matter, concentration of hydrocarbon generation, surrounding environment (such as pressure) etc.

Conventional energies and unconventional energies shall not be viewed in detached way and the existence, exploration and development of conventional oil and gas shall not be neglected due to the rise of unconventional energies. They are closely connected and are the products of different migration stages.

ISSN: 0010-8189

(C) CONVERTER 2020

www.converter-magazine.info 
Paleozoic basins in Midwest and Paleozoic multi-source rock types superimposition basins shall be researched and analyzed completely according to the integrated thinking of conventional energies and unconditional energies and be planed, explored and developed roundly.

Take Junggar Basin for example, and put it forward based on exploration target evaluation: we should increase exploration effects on shale gas, shale oil, coalbed methane, oil shale and oil sands based on conventional coal, oil, gas. On the horizon, we should consider both carboniferous, Permian and Jurassic; on the plane, the center should be shale gas, and outward stratum is oil and gas, and stratum out of outward stratum is coal, oil shale and coal bed methane.

\section{Acknowledgements}

Projects supported by Natural Science Foundation of Xinjiang Uygur Autonomous Region (project number: 2019D01A34) "Reservoir forming mechanism, occurrence characteristic and basin dynamic environment of shale gas source reservoir community".

\section{References}

[1] C.Y. Zhao, J.Q. Jin. Geology of petroliferous basins. Bei Jing: Petroleum Industry Press, 2011

[2] X.G. Tong. "Origin and distribution of unconventional oil," Acta petrolei Sinica, 2012, 33(supplement extra edition 1)

[3] C.Y. Liu, F.X. Zhang, F. Gao Fei. "Sedimentary basin reservoir (ore) system," Geology in China, vol. 34, no. 3, 2017.

[4] C.N. Zou, et al. Unconventional oil and gas geology. Bei Jing: Geology press, 2011

[5] W.Z. Zhao, D.D. He, Y. Song, et al. "China main petroliferous basins onshore basic feature of Petroleum Geology," Geological Review, 1999, 45(3)

[6] X.D. Li. "Distribution characteristics and development prospect of large oil Chinese. Petroleum exploration and development," vol.33, no. 2, 2006.

[7] C.Y. Liu, J.F. Zhao, Y.P. Ma, et al. "The formation of present situation and problems of hydrocarbon rich sag characteristics," Earth Science Frontiers, vol. 21, no. 1, 2014.

[8] J.L. Chen, Z.J. Shao, Y. Qin compiling. Energy geology. XuZhou: China University of Mining and Technology Press, 2004

[9] Chinese Academy of Sciences Energy strategy research group. China's Energy sustainable development Strategy Research Project. Bei Jing: Science Press, 2006

[10] Y.M. Yao, C.Y. Liu, Z.L. Zhao, et al. "On evaluation of Jurrasic coal-bearing source rocks and hydrocarbon generation mechanism in Yanqi basin,” Acta sedimentologica Sinica, vol. 21, no. 3, pp. 513-521, 2003.

[11] Y. Song, M.J. Chen, S.F. Cheng et al. "Progress in natural gas geological theory Chinese," Petroleum exploration and development 2004(1)

[12] Q. Zhao, H.Y. Wang, R.H. Liu et al. "Status of world shale gas development and present situation of exploration in China," Natural gas technology, vol. 3, pp. 11-14, 2008.

[13] C.B. Che, H.L. Yang, Z.J. Liu, et al. "Exploration and development prospects of oil shale resources in China," China mining magazine, vol. 9, pp. 1-4, 2008.

[14] R.S. Chen chief editor. natural gas geology.Wu Han: China university of geosciences press, 1989

[15] M. X. Cui. China Energy Development Report in 2007.Bei Jing: The social science literature press, 2007

[16] Z.F. Jia. Petroluem geology. Bei Jing: Petroleum Industry Press, 1989

[17] M.C. Li. Petroleum Migration. Bei Jing: Petroleum Industry Press, 2013

[18] C.L. Liu Cheng-lin, C.B. Che Chang-bo, Fan Ming-zhu, et al. "Chinese coal bed methane resource evaluation," China coal bed methane, vol. 3, 2009.

[19] H.K. Nie, X. Tang, R.K. Bian. "Shale gas reservoir prediction of favorable areas for development and controlling factors of shale gas in southern Chinese," Acta petrolei Sinica, vol. 4, pp. 484-491, 2009. 
[20] B.L. Pu, S. J. Bao, Y. Wang, et al. "Analysis of reservoir conditions -- to America shale gas basin for example into shale gas," Petroleum Geology and Engineering, vol. 3, pp. :33-35, 2008.

[21] Y. Qin. "A review of study on geological coal bed gas Chinese," Geological Journal of China Universities,vol. 3, 2003.

[22] Y.M. Yao, Y.M. Zhang, D.G. Fu, et al. "Relationship between paleotemperature and oil and gas formation in Bohu depression in Yanqi basin," Petroleum exploration and development, vol. 1, pp. 24-27, 2004.

[23] J.D. Jia . "Geological features and distribution rule of natural gas reservoirs in Junggar basin," Natural Gas Geoscience, vol. 16 no. 4, pp. 449-455, 2005.

[24] Y.J. Zhang compiling. Faults in the Junggar basin oil and oil and gas accumulation. Bei Jing: Petroleum Industry Press, 2010

[25] W.P. Gong compiling. The southern margin of the Junggar basin off the petroleum geological characteristics of fold belt. Bei Jing: Petroleum Industry Press, 2010 